\title{
DAMPAK PERCERAIAN ORANG TUA TERHADAP MINAT BELAJAR ANAK DI
} DESA NGADISEPI

\author{
Hamidulloh lbda ${ }^{*}$, Slamet Nastakin ${ }^{2}$ \\ STAINU Temanggung \\ h.ibdaganteng@stainutmg.ac.id \\ *Korespondensi
}

Naskah diterima: 25 Januari 2020, direvisi: 30 Maret 2020, disetujui: 10 Juni 2020

\section{Abstrak}

Perceraian tidak hanya berdampak bagi kedua orang tua, namun juga melibatkan anak khususnya yang memasuki usia remaja, perceraian merupakan beban tersendiri bagi anak sehingga berdampak pada psikis serta berimbas pada minat dan motivasi belajar anak merupakan salah satu reaksi anak terhadap perceraian orangtuanya, sangat dipengaruhi oleh cara orang tua berperilaku sebelum, selama dan sesudah perceraian.

Metode dalam penulisan ini menggunakan pengamatan dan metode deskriptif dengan menggunakan metode kualitatif, sebagai prosedur yang mendekatkan pada metode deskriptif berupa kata-kata tertulis atau lisan dari masyarakat sekitar.

Untuk mengatasi perlakuan salah tersebut, maka dalam praktik pekerjaan sosial, seorang pekerja sosial harus berupaya mewujudkan ketercapaian akan kesejahteraan bagi anak.

Kata Kunci: Perceraian, Minat Belajar

\section{Abstract}

Divorce does not only affect parents, but also involves older children, divorce is a special burden for children so it increases on the psychic. The child's reaction to his parents' divorce is strongly opposed to the way parents behave before, during and then divorce.

This method of improvement uses observations and descriptive methods using qualitative methods, as procedures related to surrounding research methods.

To overcome wrongs, in social work practices, social workers must be able to achieve achievements that will benefit children.

\section{Keywords: Divorce, Interest To Learn}




\section{PENDAHULUAN}

Keluarga memegang peran penting dan bertanggung jawab terhadap pendidikan anaknya, maka dalam keluarga harus saling ada rasa kasih sayang dan perhatian antar anggota keluarga. Apabila keluarga selalu dihiasi dengan permasalahan bahkan perceraian, maka anak akan sulit diatur, memberontak, dan bersikap negative lainnya termasuk dalam belajar'.

Lingkungan Keluarga merupakan bagian dari masyarakat terkecil untuk lingkungan pendidikan primer yang bersifat fundamental, sehingga sangat berperan dalam pembentukan akhlak dalam keluarga. Dalam hal ini yang berperan adalah orang tua, bagimana orang tua mendidik anak-anaknya.

Besar kecilnya persoalan, sumbernya kembali pada pendidikan dan pertumbuhan anak sejak dini dalam keluarga, dimana perjalanan anak manusia secara bertahap dimulai sejak terbukanya mata terhadap kehidupan, sebagai mana Nabi Muhammad saw bersabda:

"Semua bayi dilahirkan dalam keadaan suci. Ibu dan bapaknya-lah yang memegang peranan penting untuk

'Dampak-perceraian-orang-tua-terhadapkondisi-mental-dan-motivasi-belajar-pai https://docplayer.info/ membuatnya menjadi seorang Yahudi, Nasrani, atau Majusi" (HR.al-Baihaqi).

Keseimbangan di dalam kehidupan keluarga perlu dipupuk dan dijaga. Masing-masing anggota keluarga hendaknya mengetahui tugas, kewajiban dan tanggung jawabnya. Orang tua memiliki peranan penting dalam menciptakan keseimbangan hubungan yang harmonis di dalam keluarga. Orang tua sangat berperan dalam pembentukan akhlak, dan mengantarkan keberhasilan anak di dalam mengejar cita-cita pendidikannya.(Yeti Zein, 2005)

Saebani dalam bukunya Metode penelitian, penelitian merupakan salah satu Tri Darma Perguruan Tinggi yang kedudukannya sangat penting, terutama untuk pengembangan ilmu pengetahuan (Saebani,2008: 5).

Berdasarkan uraian pembahas tersebut, maka penulis tertarik untuk melakukan penelitian dengan judul "Dampak perceraian orang tua terhadap minat belajar anak di desa ngadisepi "

Dari uraian di atas, maka rumusan masalah yang akan dibahas dalam penelitian skripsi ini sebagai berikut: 
Pertama Bagaimana Dampak Perceraian Orang Tua Terhadap Motivasi Belajar Siswa Pada Pembelajaran Pendidikan Agama lslam.

Dengan memperhatikan perumusan masalah di atas maka tujuan penelitian adalah sebagai berikut :

\section{Pertama Mengetahui Dampak} Perceraian Orang Tua Terhadap Motivasi Belajar Siswa Pada Pembelajaran Pendidikan Agama Islam Di desa ngadisepi

\section{METODE}

Metode Penelitian adalah metode yang digunakan dalam aktivitas penelitian, misalnya mahasiswa melakukan penelitian guna menyusun skripsi, tesis, atau disertasi. Dalam penelitiannya, ia menggunakan metode tertentu, misalnya metode penelitian kuantitatif atau kualitatif, atau berbagai jenis metode penelitian lainnya, misalnya metode penelitian deskriptif, studi kasus, dan eksploratif (Saebani, 2008: 43).

Menurut Zuhairini dalam bukunya Filsafat Pendidikan lslam (2012), menyebutkan ada tiga macam pusat pendidikan, yaitu keluarga, sekolah dan masyarakat yang satu sama lainnya saling mempengaruhi dalam mencapai tujuan pendidikan.

$$
\text { Penelitian ini dilakukan }
$$
menggunakan metode deskriptif dengan menggunakan metode kualitatif, sebagai prosedur yang mendekatkan pada metode deskriptif berupa kata-kata tertulis atau lisan dari masyarakat sekitar untuk mengetahui data yangs sedang terjadi di masyarakat ngadisepi, teknik pengumpulan data di laukan dengan mengamati.

Penelitian ini ini dilakukan di desa ngadisepi, kecamatan gemawang.teknik pengumpulan data menggunakan observasi atau pengamatan, hasil penelitian sejenis yang telah dipublikasikan mengenai dampak perceraian orang tua terhadap minat belajar anak.

\section{HASIL DAN PEMBAHASAN}

\section{Perkawinan dan perceraian}

Pengertian dan Hukum Perkawinan

Dalam Hukum Islam dan UU No. 1 Tahun 1974 Perkawinan merupakan salah satu sunnatullah yang umum berlaku pada semua makhluk Allah, baik itu manusia, hewan maupun tumbuhtumbuhan. Semua yang diciptakan Allah 
adalah berpasang-pasangan dan berjodohjodohan, sebagaimana berlaku pada makhluk yang paling sempurna, yakni manusia.

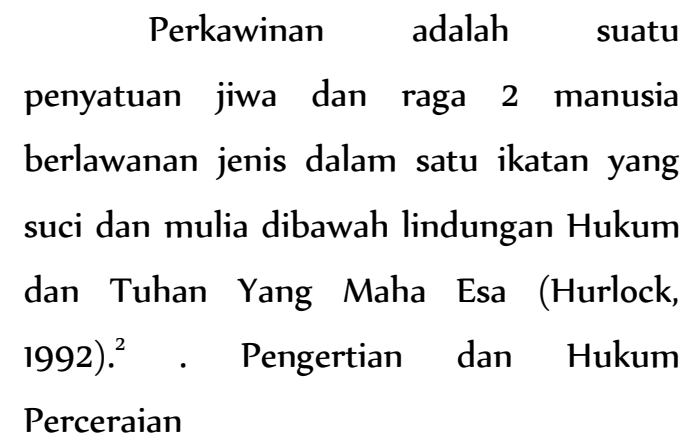

2.perceraian.

Perceraian merupakan bagian dari dinamika rumah tangga. Perceraian ada karena adanya perkawinan. Meskipun tujuan perkawinan bukan perceraian, perceraian merupakan sunnatullah, dengan penyebab yang berbeda-beda. Bercerai dapat disebabkan oleh kematian suaminya, dapat pula karena rumah tangga yang tidak cocok dan pertengkaran selalu menghiasi perjalanan rumah tangga suami istri, bahkan ada pula yang bercerai karena salah satu dari suami atau istri tidak lagi fungsional secara biologis, misalnya suami impoten atau istrinya mandul. (Ahmad Saebani, 2008: 47)

2

https://ainamulyana.blogspot.com/2012/02/motivasibelajar.html
Putusnya perkawinan adalah perceraian. Dalam istilah hukum Islam, perceraian disebut thalaq, artinya melepaskan atau meninggalkan. Menurut Sayyid Sabiq (1987: 7), “Talak artinya melepaskan ikatan perkawinan".

Seorang remaja berusia 14 tahun berinisial B yang orang tuanya bercerai sekitar 6 bulan karena ada faktor tertentu. B anak pertama dari 2 bersaudara, masih mempunyai adik yang masih duduk di sekolah dasar.ayahnya bekerja sebagai supir jasa angkut dan ibunya kerja d luar kota pulangnya 3 bulan sekali. Mereka tinggal satu dusun ketika orang tuanya mau bertemu bisa setiap hari.

Terkadang mertua si ayahnya B ingin mempersatukan dia kembali karena kasihan anak-anaknya yang masih kecil, akan tetapi si ayahnya B memiliki kenalan perempuan lain. Dari situlah B sering keuar rumah pake motor di skolahpun membawa motor dan sering pulng sore.

\section{Kebutuhan Anak}

Setiap manusia memiliki kebutuhan dasar yang mau tidak mau harus dipenuhi. Menurut Brown dan Swanson (dalam Muhidin, 2003) menyatakan bahwa kebutuhan umum anak adalah 
perlindungan (keamanan), kasih sayang, pendekatan/ perhatian, dan kesempatan untuk terlibat dalam pengalaman positif yang dapat menumbuhkan dan mengembangkan kehidupan mental yang sehat. Sedangkan menurut Katz yang dikutip oleh Muhidin (2003) menjelaskan jika kebutuhan dasar yang sangat penting bagi anak adalah hubungan orangtua dan anak yang sehat dimana kebutuhan anak seperti perhatian dan kasih sayang yang kontinu, perlindungan, dorongan, dan pemeliharaan harus dipenuhi oleh orangtua.

Selain itu, Hunttman (dalam Huraerah, 2005) merinci kebutuhan anak menjadi 10. yaitu:

1) Kasih sayang orangtua.

2) Stabilitas emosional.

3) Pengertian dan perhatian.

4) Pertumbuhan kepribadian.

5) Dorongan kreatif.

6) Pembinaan kemampuan intelektual dan keterampilan dasar.

7) Pemeliharaan kesehatan.

8) Pemenuhan kebutuhan makanan, pakaian, tempat tinggal yang sehat dan memadai.

9)

$\begin{array}{lcr}\text { Aktivitas } & \text { rekreasional } & \text { yang } \\ \text { konstruktif } & \text { dan } & \text { positif. }\end{array}$

Pemeliharaan, perawatan, dan perlindungan.

Orangtua harus memenuhi kebutuhan dasar anak dengan sebaikbaiknya supaya pertumbuhan dan perkembangan anak secara fisik, psikis, intelektual maupun sosialnya berlangsung dengan baik. Kasus yang dialami B merupakan bentuk dari pelanggaran akan pemenuhan kebutuhan anak seperti kasih sayang orangtua, stabilitas emosional, pengertian dan perhatian,pertumbuhan kepribadian dan khususnya motivasi belajar anak dalam bidang agama.

\section{Tingkat motivasi belajar anak}

motivasi adalah suatu perubahan energi di dalam diri pribadi seseorang yang ditandai dengan timbulnya afektif, dan reaksi untuk mencapai tujuan, juga sebagai dorongan dari dalam diri seseorang dan dorongan ini merupakan motor penggerak.

Oleh karena itu, motivasi sebagai proses batin atau proses psikologis yang terjadi pada diri seseorang sangat dipengaruhi oleh faktor eksternal (lingkungan) ${ }^{3}$, dan

\footnotetext{
3 https://www.alodokter.com/hilangkan-ego-inidampak-perceraian-terhadap-anak Dewi, P.S \& Utami, M.S. 2015. Subjective Well Being Anak Dari Orang Tua Yang Bercerai. Jurnal.
} 
faktor internal yang melekat pada setiap orang (pembawaan), tingkat pendidikan, pengalaman masa lalu, keinginan atau harapan masa depan.

Sebagai guru harus memberikan motivasi yang penuh terhadap proses belajar siswa dan juga memeberikan dukungan yang penuh dalam hal apapun, ketika peserta didiknya sedang ada permasalahan ,sebagai guru harus memberikan dukungan yang penuh.

Berdasarkan pengertian di atas, maka dapat disimpulkan bahwa motivasi adalah suatu proses perubahan tenaga dalam diri individu yang memberi kekuatan baginya untuk bertingkah laku (dengan giat belajar) dalam usaha mencapai tujuan belajarnya.

\section{Sedangkan belajar merupakan proses dasar dari perkembangan hidup manusia, dengan belajar manusia melakukan perubahan-perubahan kualitatif individu sehingga tingkah lakunya berkembang. Semua aktivitas dan prestasi hidup manusia tidak lain adalah hasil dari belajar, karena seseorang hidup dan bekerja menurut apa yang telah dipelajari. Belajar itu bukan hanya sekedar}

Fakultas Psikologi Universitas Gadjah Mada. Vol. 35, NO. 2, $194-212$ ISSN: 0215-8884 pengalaman, belajar adalah suatu proses, bukan suatu hasil. Oleh karena itu, belajar berlangsung aktif dan integratif dengan menggunakan berbagai bentuk perbuatan untuk mencapai hasil.

\section{Dampak Perceraian Pada Anak}

Perceraian mempunyai akibat pula, bahwa kekuasaan orang tua berakhir dan berubah menjadi "perwalian" (voogjid), Subekti 1992:44. Mereka yang putus perkawinan karena perceraian memperoleh status perdata dan kebiasaan sebagai berikut: (1) keduanya tidak terikat lagi dalam tali perkawinan, menjadi bekas suami berstatus duda dan menjadi bekas istri menjadi janda. (2) keduannya bebas melangsungkan perkawinan dengan pihak lain dengan ketentuan pihak mantan istri sudah melewati masa iddah, (3) kedua belah pihak diperkenakan menikah kembali diantara mereka sepanjang tidak bertentangan dan dilarang oleh Undangundang dan norma agama mereka (Moh. Mahfud, 2006:210). Menurut Leslie, trauma yang dialami anak karena perceraian orang tua berkaitan dengan kualitas hubungan dalam keluarga sebelumnya. Apabila anak merasakan adanya kebahagiaan dalam kehidupan rumah sebelumnya maka mereka akan meraskan trauma yang sangat berat. 
Sebaliknya bila anak merasakan tidak ada kebahagiaan kehidupan dalam rumah, maka trauma yang dihadapi anak sangat kecil dan malah perceraian dianggap sebagai jalan keluar terbaik dari konflik terus menerus yang terjadi antara ayah dan ibu ( T.O Ihromi, 2004:160). Menurut Undang-undang No 1 tahun 1974 tentang perkawinan, pasal 41 disebutkan : akibat putusnya perkawinan karena perceraian ialah : 1. Baik ibu atau bapak tetap berkewajiban memelihara dan mendidik anak-anaknya, bilamana ada perselisihan mengenai penguasaan anak pengadilan memberikan keputusan. 2. Bapak bertanggung jawab atas semua biaya pemeliharaan dan pendidikan yang diperlukan anak, bilamana bapak dalam kenyataannya tidak dapat memenuhi kewajiban tersebut, pengadilan memutuskan ibu ikut memikul biaya tersebut. 3. Pengadilan dapat mewajibkan kepada bekas suami untuk memberikan biaya penghidupan dan/atau menentukan suatu kewajiban bagi bekas istri. ${ }^{4}$

Dampak terhadap anak bila suami istri yang bercerai,pertama anak sering bermain ketika pulng sekolah kedua anak tidak di awasi sepenuhnya oleh orang tua,

\footnotetext{
${ }^{44}$ https://www.alodokter.com/hilangkan-egoini-dampak-perceraian-terhadap-anak
}

dampak psikologisnya, apabila anak tersebut masih kecil maka tidak baik terhadap perkembangan jiwa si anak, misalnya dalam bergaul dengan teman sebayanya anak merasa malu, minder, nilainya menurun di sekolah, di buly teman- temanya dan sebagainya. ${ }^{5}$

Akibat perceraian akan sangat dirasakan adalah :

a) Perasaan kehilangan arti keluarga (Kondisi ini anak merasa diabaikan, kesepian).

b) Kualitas hubungan dengan orang tua menurun (anak lebih menutup diri untuk membatasi - hubungan dengan orang tua) Membenci Orang tua

c) Rasa tidak aman

d) Sedih yang mendalam

e) Kesepian

f) $M a r a h /$ kesal $^{6}$

g) Menyendiri Perasaan tersebut yang dapat menyebabkan perubahan pada kondisi kepribadian remaja.

Remaja yang orang tuanya bercerai akan mengalami kebingungan dalam

\footnotetext{
${ }^{5}$ Dewi, P.S \& Utami, M.S. 2015. Subjective Well Being Anak Dari Orang Tua Yang Bercerai. Jurnal. Fakultas Psikologi Universitas Gadjah Mada. Vol. 35, NO. 2, $194-212$ ISSN: 0215-8884

${ }^{6}$ Dewi, P.S \& Utami, M.S. 2015. Subjective Well Being Anak Dari Orang Tua Yang Bercerai. Jurnal. Fakultas Psikologi Universitas Gadjah Mada. Vol. 35, NO. 2, $194-212$ ISSN: 0215-8884
} 
mengambil keputusan, apakah akan mengikuti ayah atau ibu. la cenderung mengalami frustasi karena kebutuhan dasarnya, seperti perasaan ingin disayangi, dilindungi rasa aman dan dihargai telah tereduksi bersamaan dengan peristiwa perceraian orang tuanya. Keluarga yang tidak harmonis, tidak stabil atau berantakan (broken home) merupakan faktor penentu bagi perkembangan kepribadian anak yang tidak sehat.

\section{KESIMPULAN}

Hingga saat ini percerian orang tua menjadi pengaruh besar dan memberikan dampak buruk bagi anaknya, dan perceraian harus dipikirkan dulu, orang tua harus bisa memberikan pengertian kepada anak sehingga dapat mengurangi dan mengatasi dampak buruk pada anak pada saat perceraian terjadi. Dampak yang di alami anak ketika orang tuanya bercerai anak bisa membenci orang tua, prestasi belajar menurun, sering keluar rumah dan berani sama orang tua.

Untuk mengatasi perlakuan salah tersebut, maka dalam praktik pekerjaan sosial, seorang pekerja sosial harus berupaya mewujudkan ketercapaian akan kesejahteraan bagi anak.

\section{DAFTAR PUSTAKA}

Aminah, Andayani, \& Karyanta. 2014. Proses Penerimaan Anak (Remaja Akhir) Terhadap Perceraian Orangtua Dan Konsekuensi Psikososial Yang Menyertainya. Jurnal. Fakultas Kedokteran Program Studi Psikologi Universitas Sebelas Maret.

Dewi, P.S \& Utami, M.S. 2015. Subjective Well Being Anak Dari Orang Tua Yang Bercerai. Jurnal. Fakultas Psikologi Universitas Gadjah Mada. Vol. 35, NO. 2, 194 - 212 ISSN: 0215-8884

Ningrum, P.Rosalia. 2013. Perceraian Orang Tua Dan Penyesuaian Diri Remaja. ejournal Psikologi, 2013, 1 (1): $\quad 69-79 \quad$ ISSN 00000000, ejournal.psikologi.fisipunmul.org.

https://ainamulyana.blogspot.com/2012/02/ motivasi-belajar.html

http://www.ejurnal. com/2014/12/ProsesPenerimaanAnakRemaja-Akhir. html> 